\title{
Topsoil translocation for Brazilian savanna restoration: propagation of herbs, shrubs, and trees
}

\author{
Maxmiller C. Ferreira ${ }^{1}$, Bruno M. T. Walter ${ }^{2}$, Daniel L. M. Vieira ${ }^{3,4}$
}

Topsoil translocation has been used for vegetation restoration throughout the world, but it has been poorly tested within savannas. This study describes Brazilian savanna (cerrado) regeneration for the first $\mathbf{3}$ years following topsoil translocation. The topsoil was stripped from 2.5 ha of savanna and spread on 1 ha of an abandoned laterite quarry in the Federal District, Brazil. We assessed vegetation structure and species composition in 18 circular plots $\left(3.14 / \mathrm{m}^{2}\right)$ after 5 and $15 \mathrm{months}$ and in 30 circular plots after 37 months. In the last floristic survey, the coverage of herbs was estimated using the step-point method. To verify the source of regeneration, a total of 181 shrubs and trees were excavated over the first 2 surveys. After 3 years, 24, 40, and 21 species of herbs, shrubs, and trees, respectively, had been recorded by the surveys. Of the 33 families found, Fabaceae, Poaceae, and Asteraceae were the most representative. At 5 and 15 months, 91 and $83 \%$ of the individuals (shrubs and trees combined) were derived from resprouting, respectively. Shrub and tree stem density reached $3.2 / \mathrm{m}^{2}$ at $5 \mathrm{months}$, but declined to $0.5 / \mathrm{m}^{2}$ at 37 months. By the final survey, native and exotic grasses completely covered the ground. Topsoil translocation was effective for the propagation of native herbs, shrubs, and trees, despite the need to control invasive grasses. The large number of shrub and tree resprouts from roots suggests that the bud bank is an important component of the topsoil for savanna restoration.

Key words: bud bank, cerrado, mining, Neotropical savanna, reclamation, resprouting ability

\section{Implications for Practice}

- Topsoil translocation effectively established native savanna species of herbs, shrubs, and trees on an abandoned laterite quarry. The topsoil can be used for restoration rather than being discarded after removal from nearby construction and mining sites.

- Root fragments should be taken into account in topsoil translocation of savannas and other sprouter-dominated communities, as their resprouts were responsible for most regenerating trees and shrubs.

- Invasive grasses should be controlled in areas restored by topsoil deposition, as they benefit from the bare ground available for colonization in the early years.

\section{Introduction}

A major objective of restoration ecology is to develop effective, fast, and inexpensive methods to restore the structural and floristic characteristics of an ecosystem. When topsoil removal is necessary for civil construction and mining, the soil may then be successfully used as a fertile substrate and a source of plants for the reclamation and restoration of degraded areas (Tacey \& Glossop 1980; Schwenke et al. 1999). Indeed, topsoil translocation has been used for the restoration of deserts, grasslands, woodlands, and forests throughout the world (e.g. Vécrin \& Muller 2003; Hall et al. 2010; Tozer et al. 2012; Golos \& Dixon 2014). Most studies find that topsoil translocation transfers a large number of seeds, therefore supporting the restoration of a community that is similar to the pre-disturbance community (Rokich et al. 2000; Vécrin \& Muller 2003). Although seedling recruitment from seeds in the topsoil is the main source of vegetation recovery (Hall et al. 2010), individuals may also regenerate from root fragments, rhizomes, corms, and tubers (Tozer et al. 2012).

The savanna ecosystem is dominated by grasses with scattered shrubs and trees. Savannas may cover up to $15 \%$ of the global land surface, and are mostly found in South America, Africa, and Australia (Haxeltine \& Prentice 1996). In South America, savannas cover approximately 270 million hectares (Solbrig et al. 1996; WWF 2015). The Brazilian savanna, also known as cerrado, once occupied about $23 \%$ of the country, but it is being converted to mechanized agriculture at a fast rate (Lapola et al. 2014), and mining and urbanization are

Author contributions: DLMV conceived the research; MCF, BMTW, DLMV designed and performed the study; BMTW identified plant species; MCF analyzed the data; MCF, BMTW, DLMV wrote and edited the manuscript.

${ }^{1}$ Departamento de Ecologia, Universidade de Brasília, Instituto de Ciências Biológicas, Bloco E, Campus Darcy Ribeiro, Asa Norte, 70910-900 Brasília, DF, Brazil

${ }^{2}$ Herbário CEN, Embrapa Recursos Genéticos e Biotecnologia, Asa Norte, Caixa Postal 02372, 70770-900 Brasília, DF, Brazil

${ }^{3}$ Laboratório de Ecologia e Conservação, Embrapa Recursos Genéticos e Biotecnologia, Asa Norte, Caixa Postal 02372, 70770-900 Brasília, DF, Brazil

${ }^{4}$ Address correspondence to D. L. M. Vieira, email daniel.vieira@embrapa.br

() 2015 Society for Ecological Restoration

doi: $10.1111 /$ rec. 12252

Supporting information at:

http://onlinelibrary.wiley.com/doi/10.1111/rec.12252/suppinfo 
increasing quickly (Pereira et al. 2012; Mineral Data 2015). Usually, the topsoil and native vegetation that are removed by these activities are discarded in waste dumps. To date, there are few studies addressing the use of topsoil for the restoration of savannas (see Gould 2012 for a study in the Australian savanna). Topsoil translocation is likely to be an effective technique for Brazilian savanna restoration because it includes a seed bank with herb and shrub species. Although herbs and shrubs represent $87 \%$ of the spermatophytes in the Brazilian cerrado (Mendonça et al. 2008), they are neglected in restoration projects because little is known about their seed and seedling biology and propagation requirements. Another advantage of topsoil translocation for savanna restoration is that the bud bank is also transferred, including rhizomes, rhizophores, xylopodia, corms, bulbs, roots, and aboveground and belowground fragments that have the potential to resprout (Gottsberger \& Silberbauer-Gottsberger 2006; Klimešová \& Klimeš 2007; Clarke et al. 2013). In cerrado physiognomies, herbs resprout from bud banks after disturbance events (Gottsberger \& Silberbauer-Gottsberger 2006; Appezzato-da-Glória et al. 2008), although they can also recruit from seeds (Williams et al. 2005). Similarly, shrubs and trees have high resprouting ability (Medeiros \& Miranda 2008), and some species propagate vegetatively after fire (Hoffmann 1998).

We evaluated the use of topsoil as a plant source to restore the savanna vegetation of an abandoned laterite quarry over a period of 3 years. The objectives were (1) to evaluate the relative contributions of true seedlings and resprouters to shrub and tree densities and (2) to assess changes in community structure and floristic composition 5, 15, and 37 months after topsoil translocation, taking into account herbs, shrubs, and trees.

\section{Methods}

\section{Study Area}

The study was conducted from December 2010 to February 2014 in the Federal District of Brazil. Mean annual precipitation in the study area is $1,394 \mathrm{~mm}$, with $86 \%$ of the rainfall concentrated between October and March. Mean temperature is $22.2^{\circ} \mathrm{C}$ in the hottest month and $18.1^{\circ} \mathrm{C}$ in the coldest month. The soil is dystrophic Oxisol (Red Latosol).

The topsoil used in this study consisted of aboveground vegetation plus soil to a depth of $40 \mathrm{~cm}$. The vegetation was removed and the soil excavated within a 2.5-ha area for the construction of buildings in the suburb of Brasília, Federal District $\left(15^{\circ} 59^{\prime} \mathrm{S}, 48^{\circ} 03^{\prime} \mathrm{O}\right.$, elevation $1,195 \mathrm{~m}$ a.s.l.). The vegetation of the removal site was cerrado stricto sensu, characterized by a continuous grass cover with sparsely distributed subshrubs, shrubs, and twisted trees. The vegetation was preserved and did not include invasive exotic grasses.

The topsoil deposition site, in a state reserve $5 \mathrm{~km}$ away from the topsoil collection area $\left(16^{\circ} 01^{\prime} \mathrm{S}, 48^{\circ} 05^{\prime} \mathrm{W}\right.$, elevation $1,040 \mathrm{~m}$ a.s.l.), was approximately 1 ha in size. The area, which used to be a laterite quarry, was excavated to a depth of $3 \mathrm{~m}$, exposing an extremely compacted clay horizon with ravines (Fig. 1A). Before mining, the deposition area had been covered by cerrado stricto sensu on a dystrophic inceptisol (cambisol), as inferred from the surrounding landscape. Half of the perimeter of the deposition site was surrounded by a typical savanna invaded by exotic grasses, mostly Andropogon gayanus, and the other half was delimited by the rest of the quarry, with very scattered Andropogon clumps.

\section{Topsoil Stripping and Translocation}

The topsoil was translocated between December 2010 and January 2011. A front loader was used to remove both the vegetation and the topsoil. The front loader moved across the field twice per strip, first removing all vegetation by stripping the soil surface to a depth of about $10 \mathrm{~cm}$, then excavating an additional $30 \mathrm{~cm}$. This procedure facilitated both vegetation and topsoil removal because the woody vegetation had not been cut with a chainsaw. These layers were combined into one pile for each strip, resulting in several piles circa $4 \mathrm{~m}$ wide $\times 15 \mathrm{~m}$ long $\times 2 \mathrm{~m}$ tall of soil mixed with litter, whole plants, root and stem fragments, branches, and seeds (Fig. 1B). Although not estimated in this study, plant fragments were found at densities of $2,220 / \mathrm{m}^{3}$ in a topsoil of tropical dry forest in the Federal District, mostly comprising root fragments (Ferreira 2015). The piles amounted to $7,500 \mathrm{~m}^{3}$ of topsoil, which remained in place for 15 days. After this period, piles were loaded into dump trucks using the front loader and transported to the deposition area. The topsoil was distributed by lifting the bucket and slowly moving the truck to form connected mounds $3 \mathrm{~m}$ wide and up to $1.5 \mathrm{~m}$ tall at the top and $0.1 \mathrm{~m}$ tall at the base, creating an irregular surface (Fig. 1C). As a result, 2.5 ha of excavated topsoil became 1 ha of deposited topsoil. In this study, it was not possible to level the topsoil mounds because deposition occurred at the peak of the rainy season, and these maneuvers would have been hampered by the front loader getting stuck in the mud and by soil sticking to the loader. By the time the soil was less wet (1 month later), germination and resprouting had already started, and this procedure would further damage them.

\section{Vegetation Sampling}

The source of shrub and tree regenerants was examined by digging 76 and 105 randomly selected individuals at 5 and 15 months, respectively. Regenerating individuals were classified as seedlings if originated from seeds, or resprouters if originated from root or stem fragments (Fig. 1D).

Community structure and species composition were evaluated 5, 15, and 37 months after topsoil translocation. For the first two surveys, all individuals within 18 randomly placed circular plots of $1 \mathrm{~m}$ radius $\left(3.14 \mathrm{~m}^{2}\right)$ were recorded, including all herbs, shrubs, and trees. At 37 months, the number of individuals and the heights of shrubs and trees were recorded in 30 plots, whereas the coverage of herbs was assessed using the step-point method because the number of herb individuals did not correlate with the amount of space occupied by them (Interagency Technical Reference 1999). In addition, it is difficult to distinguish individuals of herbaceous species in the field, especially grasses. For the step-point method, four $30-\mathrm{m}$ transects 

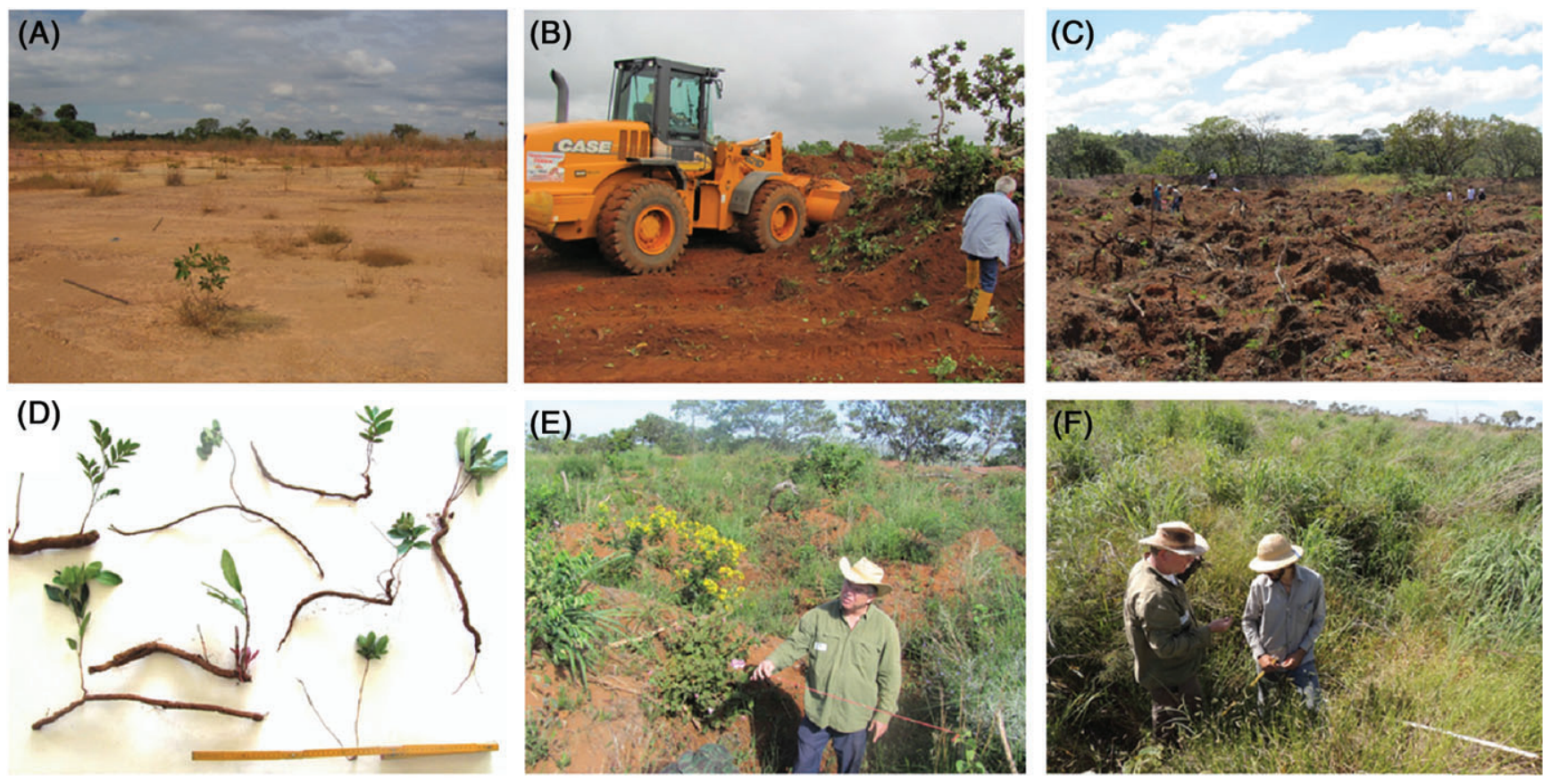

Figure 1. Stages of topsoil translocation for Brazilian savanna (cerrado) restoration in the Federal District, BR. (A) Deposition site before receiving topsoil; site was originally used for quarrying, exposing the C horizon; (B) topsoil with removed vegetation and piling; (C) deposition site after receiving topsoil; (D) shrub and tree species resprouting from root fragments; (E) deposition area 5 months after receiving topsoil, partially covered by several plant life forms, many flowering and fruiting; (F) deposition area 37 months after receiving topsoil, completely covered by native and exotic invasive grasses.

were allocated randomly and coverage was sampled every $0.5 \mathrm{~m}$ using a $2-\mathrm{m}$ tall stick subdivided into four intervals $(0-0.50$, $0.51-1.00,1.01-1.50$, and $1.51-2 \mathrm{~m})$. At each sampling point, we recorded the species identity of all life forms that touched the stick in each height class. This method was used to estimate percent cover by species or straw (dry grass) in each height class, and total ground cover was calculated by grouping height classes in each point. Considering that more than one species may touch the stick at each point, total coverage may be more than $100 \%$.

An additional floristic survey was carried out at 37 months to search for all species not sampled in the plots and step-points within the 1-ha area of topsoil deposition. Species were identified in the field or collected for comparison with bibliographic and herbarium material. Collected specimens were deposited in the herbarium CEN, Embrapa Genetic Resources and Biotechnology.

\section{Data Analyses}

We investigated the relative numbers of seedlings and resprouters of shrub and tree individuals to assess the sources of regeneration. Stem density and richness rarefaction curves for shrub and tree species were estimated over 37 months ( 3 years) based on the number of individuals. We also described the minimum and maximum heights of shrub and tree species at 37 months. Herbaceous cover was estimated by species frequencies in the 18 plots at 5 and 15 months, and by the number of step points touched by the herb species (in any height class) relative to the total number of sampled points at 37 months. We also described the vertical structure of the vegetation by estimating the percent coverage of herbs, shrubs, and trees combined, and straw (dry grass) relative to the four height intervals of the step-point samples.

\section{Results}

Three years after topsoil translocation, 21 tree species, 40 shrubs (Table S1, Supporting Information), and 24 herbs (Table S2) were recorded in the floristic survey, totaling 85 species from 33 families. The most representative families were Fabaceae, Poaceae, Asteraceae, Bignoniaceae, and Solanaceae, with 17, $10,9,6$, and 4 species, respectively. Four species were invasive exotic grasses, and the remainders were native species.

At 5 and 15 months, 91 and $83 \%$ of the individuals (shrubs and trees combined) resulted from resprouting, respectively, whereas the remainder originated from seed germination. It was not possible to distinguish between root and stem origin of resprouting fragments with certainty, but based on visual inspection their origin seemed to be root fragments (Fig. 1D). At 5 months, the density and richness of shrubs and trees were 3.2 stems per $\mathrm{m}^{2}$ and 51 species, respectively, decreasing to 2.6 stems per $\mathrm{m}^{2}$ and 43 species at 15 months and 0.5 stems per $\mathrm{m}^{2}$ and 27 species at 37 months (Fig. 2). Shrub species dominated the samples in all the three sampling dates. Shrub species ranged from 15 to $129 \mathrm{~cm}$ tall and tree species were 15 to $261 \mathrm{~cm}$ tall (Table S1). 

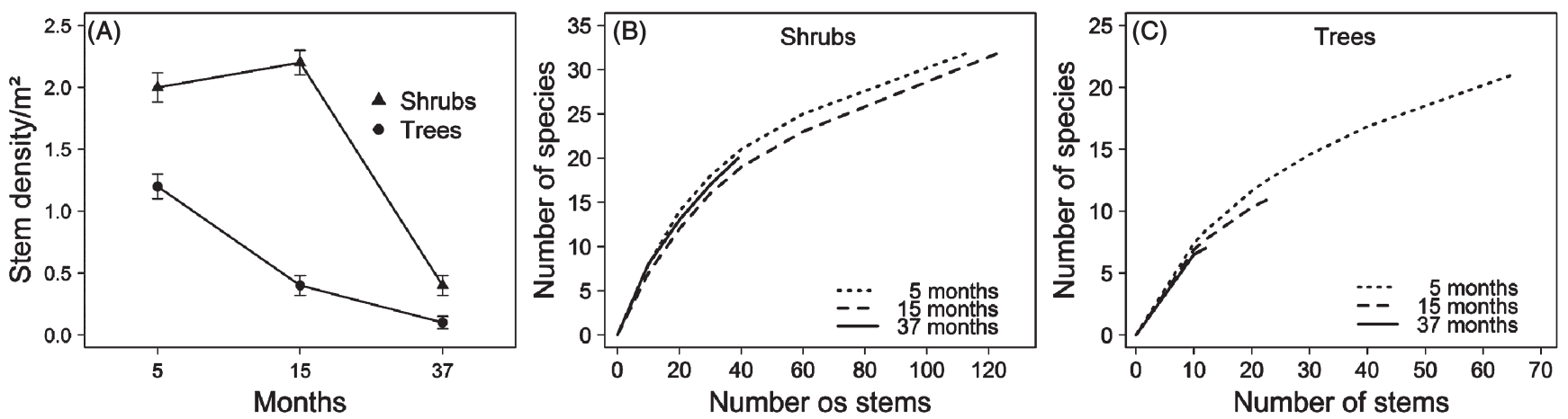

Figure 2. Shrub and tree stem density and richness after topsoil translocation in the Brazilian savanna, Federal District, BR. (A) Stem density (mean \pm 1 SE) of shrubs $(\boldsymbol{\Lambda})$ and trees $(\bullet)$ at 5, 15, and 37 months after topsoil deposition. (B) Shrub richness rarefaction curves based on individuals. (C) Tree richness rarefaction curves based on individuals. Samples taken 5 months (dotted line), 15 months (dashed line) and 37 months (full line) after topsoil deposition.

Table 1. Percent plant cover in four height classes 37 months after topsoil deposition in Federal District, BR; nomenclature: Flora do Brasil 2014 http://floradobrasil.jbrj.gov.br.

\begin{tabular}{|c|c|c|c|c|}
\hline Group/Species & $\begin{array}{l}\text { Less than } \\
0.50 \mathrm{~m}\end{array}$ & $0.5-1.0 \mathrm{~m}$ & $1.0-1.5 \mathrm{~m}$ & $1.5-2.0 \mathrm{~m}$ \\
\hline \multicolumn{5}{|l|}{ Native graminoids } \\
\hline Scleria sp. & 1 & - & - & - \\
\hline Echinolaena inflexa & 40 & 11 & - & - \\
\hline Andropogon bicornis & 5 & 5 & 4 & 1 \\
\hline Aristida sp. & 11 & 4 & 1 & - \\
\hline Panicum sp. & 2 & - & - & - \\
\hline Axonopus sp. & 1 & 1 & - & - \\
\hline Eriochloa sp. & 1 & - & - & - \\
\hline Total & 61 & 21 & 5 & 1 \\
\hline \multicolumn{5}{|l|}{ Invasive exotic grasses } \\
\hline Andropogon gayanus & 33 & 45 & 34 & 16 \\
\hline Urochloa decumbens & 21 & 16 & 7 & 1 \\
\hline Melinis minutiflora & 7 & 8 & - & - \\
\hline Total & 61 & 69 & 41 & 17 \\
\hline Straw (dry grass) & 42 & - & - & - \\
\hline Shrubs and trees & 13 & 8 & 3 & 5 \\
\hline No cover & - & 23 & 54 & 77 \\
\hline
\end{tabular}

Plant cover increased markedly over the 3 years and was associated with species turnover from annual herbs (Fig. 1E) to native and invasive exotic grasses (Fig. 1F). Annual herbaceous plants were recorded as early as 5 months after translocation, with richness and frequency peaking at 15 months, followed by no representation at 37 months (Table S2). In contrast, native and exotic invasive grasses had low frequency at 5 months, with the highest frequency at 37 months (Table S2). In the final assessment, the soil was completely covered by grasses. In the class up to $0.5 \mathrm{~m}$ in height, the cover was $61 \%$ native grasses, $61 \%$ exotic grasses, and $13 \%$ shrubs and trees. Invasive exotic grasses dominated at heights above $0.5 \mathrm{~m}$ (Table 1), especially Andropogon gayanus, which had vigorous clumps up to $2 \mathrm{~m}$ tall. The two native grass species that contributed the most to soil cover were Echinolaena inflexa and Aristida sp. (Table 1), and the two main exotic grasses were A. gayanus and Urochloa decumbens (Table 1).

\section{Discussion}

This study demonstrated that topsoil translocation, previously untested in Brazilian savanna (cerrado) restoration, has the potential to be used as a successful means of plant replacement following activities that remove topsoil from savanna areas, such as mining, urbanization, and road, railway, pipeline, and channel construction. Topsoil translocation favored the propagation of many native herbaceous and woody species, especially due to the active bud bank of root fragments transferred with the topsoil. The native grass cover was extensive and there were relatively large shrubs and trees for the length of the evaluated period. Moreover, many of these were already flowering and fruiting, forming a typical savanna physionomy. For instance, the density of shrubs and trees $\left(0.5 / \mathrm{m}^{2}\right)$ was more than four times higher than the density observed in conventional restoration plantings in Brazilian savannas, which use $3 \times 3 \mathrm{~m}$ spacing and aim to reassemble only the tree community, ignoring the fact that herbaceous and shrub strata encompass 31 and $56 \%$ of the plant species, respectively (Mendonça et al. 2008). Unfortunately, by the third year exotic invasive grasses had covered a substantial portion of the soil, and these grasses are likely to increase their dominance in the following years, preventing the expansion of native grass cover or even decreasing it. The ability of invasive grasses to out-compete native grasses in Brazilian savannas is well known (Pivello et al. 1999; Martins et al. 2004). Therefore, it is essential to control invasive grasses early in the restoration process.

\section{Shrub and Tree Species Regeneration}

Seedling recruitment from the seed bank has previously been identified as the main form of regeneration following topsoil translocation (Vécrin \& Muller 2003; Hall et al. 2010). However, the woody vegetation in the studied savanna regenerated primarily from root fragments. This result was expected because persistence by resprouting and vegetative propagation is a common trait in fire-prone ecosystems, where belowground organs like roots are important sources for resprouting (Hoffmann 1998; Medeiros \& Miranda 2008). The dominance of shrubs over trees throughout the study, both in 
terms of number of individuals and of number of species, may be explained by their higher resprouting ability (Vesk 2006) and by the high proportion of shrubs in mature Brazilian savannas, which have six times more shrub than tree species and individuals (Abdala et al. 1998; Mendonça et al. 2008).

Despite the relatively high density of shrub and tree species in the third year, density decreased from 3.2 to 0.5 stems per $\mathrm{m}^{2}$ from the 5 th to the 37 th month. This decline is consistent with our observations on plants excavated at 5 and 15 months: although root fragments did sprout shoots, the roots were very small or absent, and the survival of those individuals was not guaranteed. Many tree species are able to sprout new branches from root cuttings but are unable to sprout new roots (Vieira et al. 2013), causing a false impression of success soon after propagation. Future investigations should assess whether root sprouting and elongation would increase with a longer rainy period after topsoil deposition. In this study, the rainy season lasted from early October to early April, but topsoil deposition occurred only in early January. Therefore, advancing topsoil translocation to the early rainy season would provide three additional months of rain for the establishment of resprouters before the dry season begins. In some cases, it would also be worthwhile to test the effects of irrigation during the first dry season after topsoil deposition.

Similarily, the contribution of the seed bank to the germination of shrubs and trees has the potential to be higher than recorded in this study, as topsoil translocation occurred more than 2 months after the onset of rains, and most seeds had already germinated before topsoil removal. The seed bank of cerrado species is transient; seeds accumulate until the onset of rains, when optimum moisture conditions lead to a peak of germination (Salazar et al. 2011). Translocating topsoil before the onset of the rains would improve the efficiency of the method by increasing seed density in the soil (Rokich et al. 2000; Hosogi \& Kameyama 2004). Aside from the limited seed stock in the topsoil, the removal and deposition procedures dilute the seed bank in the deposited soil (Rokich et al. 2000; Rivera et al. 2012). This method could be improved by separating the top $5 \mathrm{~cm}$ of soil, which contains the seed bank, from the deeper soil (Tozer et al. 2012), which contains the bud bank, and depositing them in the same order.

\section{Herb Species Regeneration}

Herb cover changed quickly over the 37 months. Initially, annual herbs had the highest richness and frequency, but at the end of this study they were replaced by native and invasive exotic grasses. Annual herbs are efficient colonizers, as they form persistent seed banks that germinate and complete their life cycle quickly after soil exposure (Rapport \& Whitford 1999), in contrast to native and exotic perennial grasses, which are efficient competitors but have slower initial development and biomass accumulation (Aires et al. 2014). Although grasses may be recruited from the seed bank (Andrade \& Miranda 2014), which is transported in the topsoil, some native species also spread by stolons (Klimešová \& Klimeš 2007). An example is Echinolaena inflexa, which reproduces vegetatively (Gottsberger \& Silberbauer-Gottsberger 2006) and occupied a large proportion of the soil in this study. Grasses may also originate from seeds dispersed from the vicinity of the study area after topsoil deposition. This seems to be the case of the exotic grasses Andropogon gayanus and Urochloa decumbens, two African species that are highly invasive in Central Brazil (Horowitz et al. 2013) and very abundant in the areas surrounding the study site. In this study, invasive exotic grasses were up to $2 \mathrm{~m}$ tall and had a high cover. With their high biomass, invasive exotic grasses generally increase burning intensity and frequency to a level that is not tolerated by native grasses and shrub-tree species (Marinho \& Miranda 2013). That reinforces the need for controlling invasive grasses from the beginning of the restoration process.

\section{Acknowledgments}

We acknowledge Dr Fernando de Araújo, professor at the Instituto Federal de Brasília, for conceiving and supporting the project. Raíssa Silva, Daniel Oliveira, Dilmar Brandão, Silvia Rodrigues, and Marcio Fernandes helped with fieldwork. Beatriz Baker Méio provided English editing. Funding was provided by CNPq (MCT/CNPq/CT-Agronegócio n 26/2010, Proc. 561847/2010-0).

\section{LITERATURE CITED}

Abdala GC, Caldas LS, Haridasan M, Eiten G (1998) Above and below ground organic matter and root: shoot ratio in a Cerrado in Central Brazil. Brazilian Journal of Ecology 2:11-23

Aires SS, Sato MN, Miranda HS (2014) Seed characterization and direct sowing of native grass species as a management tool. Grass and Forage Science 69:470-478

Andrade LAZ, Miranda HS (2014) The dynamics of the soil seed bank after a fire event in a woody savanna in central Brazil. Plant Ecology 215:1199-1209

Appezzato-da-Glória BG, Cury MK, Soares M, Rocha R, Hayashi HA (2008) Underground systems of Asteraceae species from the Brazilian Cerrado. The Journal of the Torrey Botanical Society 135:103-113

Clarke PJ, Lawes MJ, Midgley JJ, Lamont BB, Ojeda F, Burrows GE, Enright NJ, Knox KJE (2013) Resprouting as a key functional trait: how buds, protection and resources drive persistence after fire. New Phytologist 193:19-35

Ferreira MC (2015) Dinâmica da regeneração natural de áreas em restauração pela transposição de solo superficial de cerrado e de floresta estacional. Master dissertation. Universidade de Brasília, Brasília, Brasil (abstract in English)

Golos PJ, Dixon KW (2014) Waterproofing topsoil stockpiles minimizes viability decline in the soil seed bank in an arid environment. Restoration Ecology 22:495-501

Gottsberger G, Silberbauer-Gottsberger I (2006) Life in the cerrado a south tropical seasonal ecosystem. I. Origin, structure, dynamics and plant use. Reta Verlag, Ulm, Germany

Gould SF (2012) Comparison of post-mining rehabilitation with reference ecosystems in monsoonal Eucalypt Woodlands, Northern Australia. Restoration Ecology 20:250-259

Hall SL, Barton CD, Baskin CC (2010) Topsoil seed bank of an oak-hickory forest in eastern kentucky as a restoration tool on surface mines. Restoration Ecology 18:834-842

Haxeltine A, Prentice IC (1996) BIOME3: an equilibrium terrestrial biosphere model based on ecophysiological constraints, resource availability, and 
competition among plant functional types. Global Biogeochemical Cycles 10:693-709

Hoffmann WA (1998) Post-burn reproduction of woody plants in a neotropical savanna: the relative importance of sexual and vegetative reproduction. Journal of Applied Ecology 35:422-433

Horowitz C, Martins CR, Walter BMT (2013) Flora Exótica no Parque Nacional de Brasília: levantamento e classificação das espécies. Biodiversidade Brasileira 3:50-73 (abstract in English)

Hosogi D, Kameyama A (2004) Timing for the collection of topsoil from a deciduous forest for use as planting material in suburban Tokyo, Japan. Ecological Engineering 23:371-386

Interagency Technical Reference (1999) Sampling vegetation attributes. BLM Technical Reference 1734-4, National Business Center, Denver, CO. 158 p

Klimešová J, Klimeš L (2007) Bud banks and their role in vegetative regeneration - a literature review and proposal for simple classification and assessment. Perspectives in Plant Ecology, Evolution and Systematics 8:115-129

Lapola DM, Martinelli LA, Peres CA, Ometto JPHB, Ferreira ME, Nobre CA, et al. (2014) Pervasive transition of the Brazilian land-use system. Nature Climate Change 4:27-35

Marinho S, Miranda HS (2013) Efeito do fogo anual na mortalidade e no banco de sementes de Andropogon gayanus Kunth. no Parque Nacional de Brasília/DF. Biodiversidade Brasileira 3:149-158 (abstract in English)

Martins CR, Leite LL, Haridasan M (2004) Molasses grass (Melinis minutiflora P. Beauv.), an exotic species compromising the recuperation of degraded areas in conservation units. Revista Árvore 28:739-747 (abstract in English)

Medeiros MB, Miranda HS (2008) Post-fire resprouting and mortality in Cerrado woody plant species over a three-year period. Edinburgh Journal of Botany 65:53-68

Mendonça RC, Felfili JM, Walter BMT, Silva MCJ, Rezende AV, Filgueiras TS, Nogueira PE, Fagg CW (2008) Flora vascular do Bioma Cerrado: checklist com 12.356 espécies. Pages 443-1181. In: Sano SM, Almeida SP, Ribeiro JF (eds) Cerrado: ecologia e flora. EMBRAPA Informação Tecnológica, Brasília, Brazil

Pereira PAA, Santana CAM, Alves E (2012) The development of Brazilian agriculture: future technological challenges and opportunities. Agriculture \&Food Security 1:1-12

Pivello VR, Carvalho VMC, Lopes PF, Peccinini AA, Rosso S (1999) Abundance and distribution of native and alien grasses in a "Cerrado" (Brazilian Savanna) Biological Reserve. Biotropica 31:71-82

Rapport DJ, Whitford WG (1999) How ecosystems respond to stress. BioScience 49:193-203

Rivera D, Jáuregui MB, Peco B (2012) The fate of herbaceous seeds during topsoil stockpiling: restoration potential of seed banks. Ecological Engineering 44:94-101
Rokich DP, Dixon KW, Sivasithamparam K, Meney KA (2000) Topsoil handling and storage effects on woodland restoration in Western Australia. Restoration Ecology 8:196-208

Salazar A, Goldstein G, Franco AC, Miralles-Wilhelm F (2011) Timing of seed dispersal and dormancy, rather than persistent soil seed-banks, control seedling recruitment of woody plants in Neotropical savannas. Seed Science Research 21:103-116

Schwenke GD, Mulligan DR, Bell LC (1999) Soil stripping and replacement for the rehabilitation of bauxite-mined land at Weipa. I. Initial changes to soil organic matter and related parameters. Australian Journal of Soil Research 38:345-369

Solbrig OT, Medina E, Silva JF (1996) Biodiversity and savanna ecosystem. Springer, Berlin, Germany

Tacey WH, Glossop BL (1980) Assessment of topsoil handling techniques for restoration of sites mined for bauxite within the Jarrah forest of Western Australia. Journal of Applied Ecology 17:195-201

Tozer MG, Mackenzie BDE, Simpson CC (2012) An application of plant functional types for predicting restoration outcomes. Restoration Ecology 20:730-739

Vécrin MP, Muller S (2003) Top-soil translocation as a technique in the recreation of species-rich meadows. Applied Vegetation Science 6:271-278

Vesk PA (2006) Plant size and resprouting ability: trading tolerance and avoidance of damage? Journal of Ecology 94:1027-1034

Vieira DLM, Coutinho G, Rocha GPE (2013) Resprouting ability of dry forest tree species after disturbance does not relate to propagation possibility by stem and root cuttings. Restoration Ecology 21:305-311

Williams PR, Congdon RA, Grice AC, Clarke PJ (2005) Germinable soil seed banks in a tropical savanna: seasonal dynamics and effects of fire. Austral Ecology 30:79-90

WWF (2015) Ecoregions. http://wwf.panda.org/about_our_earth/ecoregions/ ecoregion_list/ (accessed 14 April 2015)

\section{Supporting Information}

The following information may be found in the online version of this article:

Table S1. Floristic list of shrubs and trees species observed or sampled after topsoil translocation in the Federal District, BR. For the excavated species (76 and 105 randomly selected stems at 5 and 15 months, respectively), the source of regeneration was categorized as resprouting (R) or seed germination (S). For species sampled within $3.14 \mathrm{~m}^{2}$ plots $(N=30$ plots $)$, the number of stems and minimum and maximum heights are shown. Nomenclature: Flora do Brasil 2014. http://floradobrasil.jbrj.gov.br. Table S2. Floristic list of herb species observed or sampled after topsoil translocation in Federal District, BR. Frequency (\%) is shown for the species sampled in $3.14 \mathrm{~m}^{2}$ plots $(N=18$ plots) at 5 and 15 months and in 248 step points at 37 months. ${ }^{\mathrm{a}}$ Calculation based on plots; ${ }^{\mathrm{b}}$ calculation based on step points; *absent in the final survey. Nomenclature: Flora do Brasil 2014. http://floradobrasil.jbrj.gov.br.

Received: 13 January, 2015; First decision: 19 February, 2015; Revised: 12 June, 2015; Accepted: 13 June, 2015; First published online: 20 July, 2015 